\title{
Coping with Negative Work Experience and Work-related Family Issues: Spirituality as A Buffer against Emotional Exhaustion and Work-Family Conflict
}

\author{
Haui-Ren Liang ${ }^{1}$, Huai-Liang Liang ${ }^{2} \&$ Chi-Kuo Sun ${ }^{1}$ \\ ${ }^{1}$ Department of Business Administration, National Chiayi University, Chiayi, Taiwan \\ ${ }^{2}$ Department of Logistics Management, Air Force Institute of Technology, Gangshan, Taiwan \\ Correspondence: Dr. Huai-Liang Liang, Department of Logistics Management, R.O.C. Air Force Institute of \\ Technology, No. 1, Sec. 1, Syuecheng Rd., Dashu Dist., Kaohsiung City 840, Taiwan. Tel: 886-929-346678. \\ E-mail: huai-liang@yahoo.com.tw
}

Received: February 1, 2016

Accepted: February 4, 2016

Online Published: February 26, 2016

doi:10.20849/abr.v1i1.13

URL: http://dx.doi.org/10.20849/abr.v1i1.13

\begin{abstract}
The current research examined the effects of psychological contract breach on employees' work to family conflict and their partners' family-work conflict. This study also investigated the buffering effect of employee spirituality on the employees' emotional exhaustion caused by such conflicts. Analysis of a sample of 235 employee-partner dyads (188 men, 47 women, $M$ age $=44 \mathrm{yr}$.) from a plastics corporation in Taiwan found as positive relationship between psychological contract breach and family issues, through employee's emotional exhaustion. Employees with high spirituality were discovered to weaken the relationships between psychological contract breach and employees' emotional exhaustion and both family issues. This study highlighted the value of psychological contract breach on family issues from work to family in further research.
\end{abstract}

Keywords: psychological contract breach, emotional exhaustion, work to family conflict, family to work conflict, spirituality at work

\section{Introduction}

\subsection{Introduce the Problem}

Psychological contract or fulfilled expectation has been defined as an employment relationship that employees have about what they owe their employers and what their employers owe them in return (Rousseau, 1995). However, when employees perceive that the psychological contract has been breached-that is, if they feel their employer might not fulfill these expectations or promises, or that their employer may terminate them for an unknown reason-these employees might harbor unpleasant feelings toward their employer, which may cause them to behave negatively in the workplace (Morrison \& Robinson, 1997). Previous studies have focused on the effects of psychological contract breach (hereafter PCB) in the workplace to better understand the dynamics of current employment relationships (Conway, Guest, \& Trenberth, 2011; Montes \& Irving, 2008). For example, the breach of psychological contract often results in negative attitudes and behaviors, such as job dissatisfaction, turnover intention, and workplace deviance (Bal \& Kooij, 2011; Proost, van Ruysseveldt, \& van Dijke, 2012; Zhao, Wayne, Glibkowski, \& Bravo, 2007). However, research has not focused on the likelihood that such a negative workplace event is also likely to have an influence on employees' family life (Culbertson, Mills, \& Fullagar, 2012).

Andrews and Withey (1976) showed that employees' work and family are two of the most essential fields of their life. Employees' family issues may be influenced by a negative workplace event. Indeed, other studies have shown that work in general exerts a clear impact on family life (Culbertson, Mills, \& Fullagar, 2012). For example, Schwab, Jackson, and Schuler (1986) indicated that when employees' impressions fall short of expectations, the resulting emotional exhaustion affected their family lives. Therefore, this study addressed the issue mentioned above by intending the mediating individual role of emotional exhaustion on the relationship between PCB and family life. Emotional exhaustion, which is a primary component of burnout, refers to a psychological reaction to work-related pressure (Maslach, Schaufeli, \& Leiter, 2001). Based on conservation of resources (COR) theory (Hobfoll, 1989), emotional exhaustion is likely to be influenced by contextual factors in 
the workplace, and results in employees' behaviors, such as job performance (Halbesleben \& Bowler, 2007). However, this study argues that emotional exhaustion is mediated by the relationship between PCB and family issues, particularly work-family conflict.

\subsection{Explore Importance of the Problem}

Work-family conflict has frequently been studied as a source of stress that develops when work and family priorities become mutually incompatible (Greenhaus \& Beutell, 1985). When employees perceive that their organizational agents have failed to meet expectations, they frequently experience high levels of burnout (Chambel \& Oliveira-Cruz, 2010), and may entertain thoughts of leaving their employment (Dulac, Coye-Shapiro, Henderson, \& Wayne, 2008). Although studies have demonstrated that job stressors significantly relate to work-family conflict (hereafter, WFC) and family-work conflict (hereafter FWC) (e.g., Frone, Russell, \& Cooper, 1992), this research has focused on the possible relationships that connect employees' perception of PCB to negative family outcomes. A part model of this study incorporates the relationships between not only PCB and employees' WFC, but also extends employees' negative work environment to family partners' non-work experiences (Hoobler \& Hu, 2013).

Thus, this study examines PCB experienced by employees at work. More specifically, this study aims to examine whether employees and their partners at home would be affected by employees' perception of PCB at the workplace. Prior studies investigated the approaches that religious beliefs impact and workplace behaviors (e.g., organizational citizenship behavior and job satisfaction) (Kutcher, Bragger, Rodriguez-Srednicki, \& Masco, 2010). However, a limited amount of research has focused on the ways that employees cope with the negative outcomes of PCB. Ashmos and Duchon (2000) suggested that, to mitigate such outcomes, employees should utilize positive thoughts grounded in traditional religious imagery, and should engage in activities such as self-rediscovery, renewal, and the cultivation of utopian visions. Additionally, Fox (1994) revealed that people who maintain positive inner thoughts can often lead more meaningful and productive outer lives. The current study also examined the effects of spirituality as a buffer against the negative outcomes of PCB by specifically examining employees who see the workplace as no longer merely a place for earning a living but also one that provides opportunities for self-discovery, meaning and purpose (Laabs, 1995).

Extensive research has demonstrated a correlation between negative work events and undesirable employee reactions to these events (Rousseau, 1989). PCB can be associated with increased work dissatisfaction and intention to leave, mediated by emotional exhaustion (Proost et al., 2012). The breach can also negatively impact affective wellbeing, increase psychological distress, and decrease job satisfaction and career success (Conway, Guest, \& Trenberth, 2011; Restubog, Bordia, \& Bordia, 2011). Employees who perceive that their psychological contracts have been breached may struggle to set aside the negative emotions (e.g., anger) they experience at work upon their return home (Rousseau, 1989).

In light of the potentially far-reaching effects of this phenomenon, breached contracts can negatively affect employees across various roles in multiple domains. Specifically, spillover results when the transmission of emotions from work to family causes one domain to impact the other domains (Edwards \& Rothbard, 2000; Staines, 1980). As the employee-employer relationship involves the exchange of employees' time and effort for the socio-emotional benefits provided by organizations (Aselage \& Eisenberger, 2003), employees whose expectations are unmet are more likely to carry negative stress into the family domain in ways that affect their interactions in their homes. WFC is a form of inter-role conflict that the role demands from work make it more difficult for people to play family roles (Greenhaus \& Beutell, 1985).

\subsection{State Hypotheses and Their Correspondence to Research Design}

Previous studies have shown that PCB can cause a number of adjustment issues, including decreased affective commitment (Cassar \& Briner, 2011) and decreased trust (Dulac et al., 2008). Some research has shown that PCB can be associated with emotional exhaustion (e.g., Lee \& Ashorth, 1996) and negative employee behaviors toward the organization (cf. Bal, Lange, Jansen, \& Van Der Velde, 2008). Based on conservation of resources theory (Hobfoll, 1989), the depletion of employee resources to cope with employer's relationships may lead to emotional exhaustion. Exhausted employees may feel less able to take care of family demands, such as childcare. In turn, when job-related issues negatively affect employees' social relationships with their children (Repetti, 1994), workers may lack the energy to undertake extra family responsibilities, such as carrying sick children. Therefore, this study hypothesized that the effects of PCB will transfer from the professional domain to the family domain (in the form of WFC) due to emotional exhaustion. Therefore:

Hypothesis 1: The relationship between PCB and employees' work-family conflict is mediated by employees' emotional exhaustion. 


\subsubsection{Crossover Mechanism of PCB and Family-Work Conflict}

Work-family researchers have emphasized that a more realistic analysis of organizational events should include the employee's home-life (e.g., Bakker, Demerouti, \& Dollard, 2008; Ferguson, 2012; Gooke \& Rousseau, 1984; Westman, Vinokur, Hamilton, \& Roziner, 2004). However, the crossover effect of PCB in family domain has been not attended. Additionally, Westman (2001) had focused on a better understanding of factors that is likely to affect the crossover process in this scenario.

When PCB occurs, employees may manifest frustration and anger, the key constituents of emotional exhaustion (Maslach \& Jackson, 1981; Proost et al., 2012; Robinson \& Morrison, 2000). These negative reactions associate with Weiss and Cropanzano's (1996) affective events theory (AET) that states that a negative event in the workplace will result in negative reactions, and then increase the negative emotions and motivations over time (Morrison \& Robinson, 1997). These negative emotions may leave employees ill-armed to manage needs in the family domain, potentially placing additional demands on partners and increasing FWC (Schwab, Jackson, \& Schuler, 1986). Indeed, Westmen and Etzion (1995) found that burnout can transfer between spouses. FWC is a form of interrole conflict that the role demands from families make it more difficult for people to play work roles (Greenhaus \& Beutell, 1985).

However, such findings have not been framed within the specific context of studies on PCB. Although researchers have directly investigated the consequences of PCB (e.g., Conway, Guest, \& Trenberth, 2011), and have indirectly examined some mediating effects that may influence these consequences (e.g., Proost et al., 2012), the manner in which PCB may indirectly affect employees' partners has remained largely unexplored. One distinct exception is a study by Schwab, Jackson, and Schuler (1986), which found that employees' family issues are likely to be affected by emotional exhaustion resulting from discrepancies between employee expectations and organizational practices-a finding which deserves further examination. Thus:

Hypothesis 2: The relationship between PCB and partners' family-work conflict is mediated by employees' emotional exhaustion.

\subsubsection{Spirituality as a Moderator of Emotional Exhaustion, Work-Family Conflict, and Family-Work Conflict}

This study examined the effects of spirituality as a moderator of emotional exhaustion in the workplace and, consequently, WFC and FWC-a relationship that has not been empirically examined. In particular, this study argues that spirituality can help employees combat the negative effects of PCB, particularly employees' emotional exhaustion related employees' WFC and partners' FWC.

Spirituality, in the context of this study, is not a concept specific to any religion, or to religious expression or imagery. Rather, this study defines spirituality as a method by which employees' souls can be nourished at workplace (Rego \& Cunha, 2008), and employees find spiritual meaning in their lives beyond simple task performance (Fox, 1994). PCB studies in recent decades have transformed many workplaces into unhealthy environments that produce depressed employees (e.g. Zhao et al., 2007); however, an increasing, body of evidence suggests that organizations can encourage employees to pursue spirituality to nourish their inner lives and create meaningful outer lives (Vaill, 1998).

Based on Grzywacz and Marks' (2000) positive spillover model, spirituality is a psychological resource that can be used to pursue personal transformation and self-discovery (Ashmos \& Duchon, 2000), and may help employees derive additional benefits from job-related resources that may in turn positively affect job performance and family interactions. In addition, spirituality may help foster a sense of connection between employees and organizations (Ashmos \& Duchon, 2000; Hackman \& Oldham, 1975). Therefore, it is possible that employees who rely on strong positive spirituality at work might be less likely to react negatively to adverse events (i.e., PCB). Therefore:

Hypothesis 3: The relationship between PCB and employees' emotional exhaustion is moderated by employees' spirituality at work such that the link between these two factors is weaker for individuals who possess strong spirituality at work than for individuals who possess weak spirituality at work.

Research has suggested that spirituality at work is positively linked to professional dignity, a sense of meaning, and devotion to one's work (Wheatley, 1992). These factors allow employees to adjust their goals so they can adequately cope with the psychological demands they may encounter during negative events that occur in their workplaces (Bakker \& Demerouti, 2007) or elsewhere. Indeed, Fox (1994) found spirituality to be a source of strongly positive emotions in both home and work domains. Based on this logic, as well as the previously established understanding of the link between PCB, employees' emotional exhaustion, and employees' WFC/partners' FWC, this study suggests a mediated moderation model in which spirituality at work moderates 
the mediated negative outcomes of PCB (see Figure 1). Thus:

Hypothesis 4a: The effect of PCB on employees' work-family conflict, mediated by employees' emotional exhaustion, is moderated by employees' spirituality.

Hypothesis 4b: The effect of PCB on partners' family-work conflict, mediated by employees' emotional exhaustion, is moderated by employees' spirituality.

\section{Method}

\subsection{Procedures and Participants}

The current study employed two data collection approaches: surveys completed by participants and their spouses. A total of 300 full-time employees from a plastics corporation in Taiwan participated in this study. These voluntary employees were asked to complete the surveys after an employee training. This study used two survey periods for employees and one period for their partners. A total of 265 usable surveys were returned at Time 1.

One month after Time 1 (Time 2), 265 employees completed the second surveys in their workplaces and each had used their partners who completed surveys. Employees' partners completed and returned separate surveys in sealed, postage-paid envelopes provided furnished by the study. To facilitate response matching, all participants were asked to include their partners' personal information, including ID numbers and birthdates. At Time 2, 250 employee-spouse dyads (500 individuals) returned usable questionnaires, a return rate of $94 \%$. After excluding surveys containing missing and unavailable data, the final 235 dyads (470 individuals) comprised 188 (80\%) of the male employees, ranging in age from 28 to 68 years $(M=45.6$ years), and $47(20 \%)$ female employees, ranging in age from 27 to 62 years $(M=42.3$ years). Participants worked an average of 42 hours per week ( $S D=$ 13.60) and had a maximum of five children and a minimum of zero children.

\subsection{Measures}

Surveys were administered in Mandarin. To ensure the content equivalence of the Chinese and English versions, native speakers scrutinized all scales used in this study via a back-translation procedure (Brislin, 1980). Participants responded to all survey items by using a five-point scale, ranging from $1=$ strongly disagree to $5=$ strongly agree.

Psychological contract breach. To assess the presence of PCB at Time 1, this study used Robinson and Morrison's (2000) five-item measure $(\alpha=.91)$. A sample item stated, "Almost all promises made by my employer during recruitment have been kept so far" (reverse scored).

Spirituality at work. This study used the 21-item subscale developed by Ashmos and Duchon (2000) for their "The Meaning and Purpose at Work Questionnaire" at Time 1. This measure for employees includes three subscales: conditions for community (nine items), meaning at work (seven items), and inner life (five items). The coefficient alpha value for this scale was .95. Sample items included, "When I have a concern, I bring it to the appropriate person," "I experience joy in my work," and "I feel hopeful about life."

Emotional exhaustion. At Time 2, this measure for employees was assessed with the burnout inventory developed by Schaufeli, Leiter, Maslach, and Jackson (1996). The scale includes five items (e.g., "At the end of a weekday, I feel exhausted"), with a coefficient alpha value of .85 .

Work-family conflict. At Time 2, this study used the nine-item scale to measure employees' levels of WFC (Gutek, Searle, \& Klepa, 1991). A sample item stated, "Stress at work makes me irritable at home." The Cronbach's alpha for this scale was .85 .

Family-work conflict. At Time 2, this study employd a nine-item scale developed by a study of Carlson, Kacmar, and Williams (2000) to assess partners' levels of FWC. Participants used a five-point scale to show the level to which they agreed with each item $(1=$ strongly disagree, $5=$ strongly agree), with a Cronbach's alpha value of .96. Samples item included, "Owing to stress at home, I am often preoccupied with family matters at work."

Control variables. Data analyses controlled for respondents' ages, gender, job positions, number of children, and work hours to minimize the effects of demographic characteristics, as these variables are frequently used in work-family interfaces and work stress research (Maslach, Schaufeli, \& Leiter, 2001; Westman \& Etzion, 2005).

\section{Results}

\subsection{Preliminary Analyses}

Before assessing the hypotheses, the current research conducted confirmatory factor analyses (CFA) to examine the construct validity of the variables in this study. Table 1 shows that the five-factor model with PCB, employee spirituality at work, employees' emotional exhaustion, employees' WFC and partners' FWC fitted the data better 
$\left(\chi^{2}(235)=919.47 ; d f=179 ;\right.$ RMSEA $=.08(p<.05) ;$ CFI $=.95$, and PGFI $\left.=.60\right)$ than the other four models that reduced the number of factors by combining some of the five-factor into one factor. Alternative models $1,2,3$ and 4 revealed significantly poorer fit than the baseline model of this study according to the chi-square and model fit index differences (see Table 1). Based on inspection of factor loading and factor covariance, this study conducted that the measurement of the psychological variables in this study had accomplished satisfactory psychometric reliability.

Acceptable fit indices were applied to the hypothesized five-factor model (i.e., with PCB, emotional exhaustion, employees' WFC, partners' FWC, and spirituality at work each loaded onto their specific factors), yielding the following: $\chi^{2}(235)=919.47 ; d f=179$; RMSEA $=.08(p<.05)$; CFI $=.95$, and PGFI $=.60$. These results were close to model fit indices, providing sufficient confidence to test the hypotheses.

Table 1. Comparison of measurement models

\begin{tabular}{cccccccc}
\hline Model & $\chi^{2}$ & $d f$ & $\Delta \chi^{2}$ & $\Delta d f$ & RMSEA & CFI & PGFI \\
\hline 1. Five-factor model $^{2}$ & 919.47 & 179 & - & - & .08 & .95 & .60 \\
2. Four-factor model 1 $^{\mathrm{a}}$ & $1197.59^{* *}$ & 183 & 278.12 & 4 & .10 & .90 & .53 \\
3. Four-factor model 2 $^{\mathrm{b}}$ & $1386.72^{* *}$ & 183 & 467.25 & 4 & .12 & .85 & .51 \\
4. Three-factor model $^{\mathrm{c}}$ & $1483.29^{* *}$ & 186 & 563.82 & 7 & .12 & .83 & .50 \\
5. Two-factor model $^{\mathrm{d}}$ & $1705.80^{* *}$ & 188 & 786.33 & 9 & .15 & .80 & .48 \\
6. One-factor model $^{*}$ & $1988.54^{* *}$ & 189 & 1069.07 & 10 & .18 & .77 & .45 \\
\hline
\end{tabular}

Note. $\Delta \chi^{2}$ denote differences between the five-factor model and other models. $* * p<.01$

a: Four-factor model 1 combines PCB and employee spirituality at work into one factor.

b: Four-factor model 2 combines employees' WFC and partners' FWC into one factor.

c: Three-factor model combines employees' emotional exhaustion, employees' WFC, and partners' FWC into one factor.

d: Two-factor model combines employee spirituality at work, employees' emotional exhaustion, employees' WFC, and partners' FWC into one factor.

\subsection{Tests of Model Fit}

Table 2. Comparison of structural equation models for spillover and crossover models

\begin{tabular}{llllllll}
\hline Model & $\chi^{2}$ & $d f$ & $\Delta \chi^{2}$ & $\Delta d f$ & RMSEA & CFI & NNFI \\
\hline Theoretical model $^{a}$ & 16.61 & 3 & - & - & .08 & .96 & .92 \\
${\text { Alternative model } 1^{b}}^{b}$ & 15.26 & 2 & 1.35 & 1 & .12 & .96 & .88 \\
Alternative model 2 $^{c}$ & 15.65 & 2 & .33 & 1 & .12 & .96 & .87 \\
Alternative model 3 $^{d}$ & 14.69 & 1 & 1.92 & 2 & .17 & .96 & .74
\end{tabular}

Note. $\Delta \chi^{2}$ denote differences between the five-factor model and other models.

a. Theoretical model: full mediations.

b. Alternative model 1: one full mediation ( $P C B \rightarrow$ Partner FWC); one partial mediation.

c. Alternative model 2: one full mediation ( $P C B \rightarrow$ Employee WFC); one partial mediation.

d. Alternative model 3: two partial mediations.

This study examined the hypotheses for both the spillover and crossover models by structural equation modeling (SEM) with LISREL 8.8 (Jöreskog \& Sörbom, 2006). The theoretical model of this study reveals full mediating models at Table 3. In addition, Table 3 indicates that the theoretical model showed a fair fit $\left(\chi^{2}(235)=16.61, d f\right.$ $=3 ; \mathrm{RMSEA}=.08 ; \mathrm{CFI}=.96$, and NNFI $=.92$ ). In alternative models $1-3$, the results provided acceptable fit to the data (see Table 3). Thus, these results implied that the theoretical model best fitted the data of this study 
under the principle of model parsimony.

\subsection{Hypothesis Testing}

The results in Table 3 report the descriptive statistics and correlations for the study variables. There was a significantly positive relationship between PCB and employees' WFC $(r=.41 ; \mathrm{p}<.01$; see Table 3$)$ in the spillover model. In addition, this study found that PCB significantly related to partners' $\mathrm{FWC}(\mathrm{r}=.26 ; \mathrm{p}<.01$; see Table 3) in the crossover model. Furthermore, hierarchical multiple regression analyses were performed separately for the two types of moderating effects (i.e., mediation and moderated mediation) in this study. Data were analyzed for potentially mediating relationships (Hypotheses 1 and 2) using the approach developed by Baron and Kenny (1986), while the moderated mediation model (Hypotheses 4a and b) was tested using Edwards and Lambert's (2007) approach. This study also used a Sobel test advocated by Preacher and Hayes $(2004 ; 2008)$ to assess moderated and indirect relationships.

Table 4 summarizes the demographic characteristics of usable sample dyads $(\mathrm{N}=235 ; 470$ individuals), along with means, standard deviations, Cronbach alpha coefficients, and correlations. The results of the regression analyses (see Tables 4 and 5) supported Hypotheses 1 and 2, suggesting that PCB positively related to employees' emotional exhaustion, employees' WFC ( $\mathrm{t}=6.89, \mathrm{p}<.00$; see Table 2$)$, and partners' FWC $(\mathrm{t}=4.03, \mathrm{p}<.00$; see Table 3).

Table 3. Means, standard deviations, cronbach's alpha, and intercorrelations among study variables

\begin{tabular}{lllllllllllll}
\hline Variable & $M$ & $S D$ & 1 & 2 & 3 & 4 & 5 & 6 & 7 & 8 & 9 & 10 \\
\hline 1. Age & 45.66 & 8.70 & & & & & & & \\
2. Gender & 1.20 & .40 & $-.19^{* *}$ & & & & & & \\
3. Job position & 2.88 & .88 & $-.19^{* *}$ & .08 & & & & & \\
4. Number of children & 1.42 & 1.01 & $.42^{* *}$ & -.11 & $-.28^{*}$ & & & & \\
5. Work hours & 42.64 & 13.60 & -.07 & -.09 & .09 & -.03 & & & \\
6. PCB & 2.96 & .82 & .12 & $-.13-.16^{*} .06$ & $-.12(.91)$ & & \\
7. Employee spirituality & 3.31 & .78 & -.08 & -.06 .02 & .09 & .03 & $-.35^{* *}(.84)$ & & \\
8. Employees' emotional exhaustion & 2.90 & .84 & .12 & $-.12-.16^{*} .12$ & .07 & $.50^{* *}$ & $-.29^{* *}(.85)$ & \\
9. Employees' WFC & 2.84 & .91 & $.17^{*}$ & $-.06-.12$ & $.15^{*} .03$ & $.41^{* *}$ & $-.17^{* *} .74^{* *}(.85)$ \\
10. Partners' FWC & 2.92 & .93 & .12 & $-.02-.15^{*} .05$ & $-.10 .26^{* *}$ & $-.28^{* *} .43^{* *} .47^{* *}(.96)$
\end{tabular}

Note. Coefficient alphas are in parentheses on the diagonal.

$* P<.05 ; * * P<.01$.

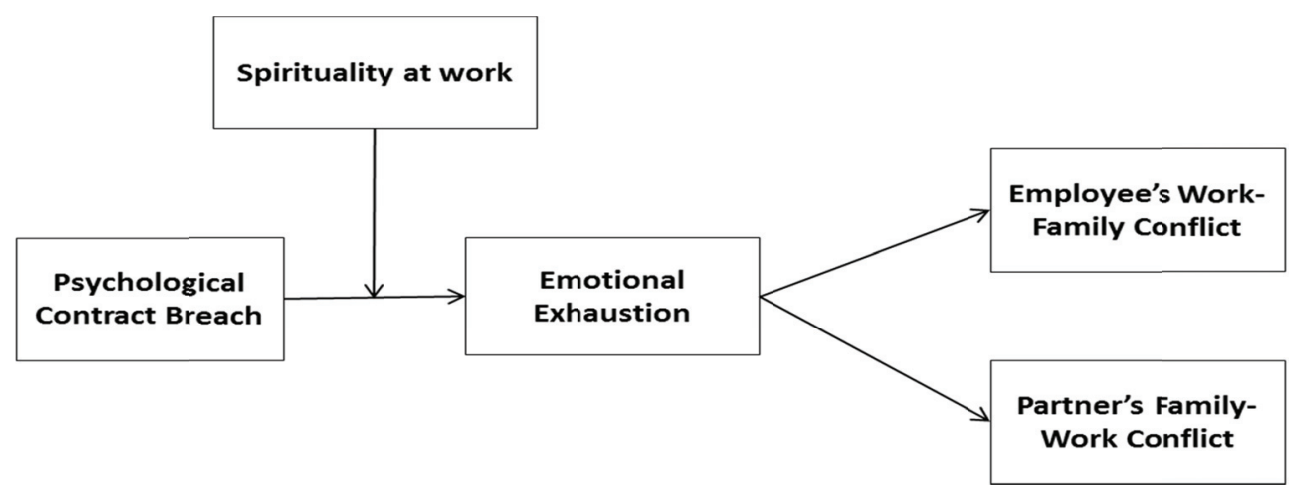

Figure 1. A mediated moderation model of the interrelationships between the central variables in this study

Table 4 shows the simple mediation analysis used to examine Hypothesis 1, which states that employees who experience PCB will subsequently experience employees' WFC, mediated by employees' emotional exhaustion. As shown in step 1 of Table 4, a positive relationship was observed between PCB and employees' WFC. The lower half of Table 4 presents the Sobel test of the mediation analysis, which indicates that employees' emotional 
exhaustion mediates the relationship between PCB and employees' WFC. Step 4 of Table 4 demonstrates that the relationship between PCB and employees' WFC was significant when controlling for employees' emotional exhaustion $(t=1.02, p>.05)$, suggesting full mediation. Based on the Sobel test recommended by Preacher and Hayes $(2004 ; 2008)$, the $95 \%$ confidence interval of the indirect effect did not include zero (from .29 to .50). Furthermore, the Sobel test of this mediation analysis provided that the indirect effect of employees' emotional exhaustion was significant $(z=7.50, p<.01)$; thus, Hypotheses 1 was supported.

Table 4. Mediation of employee's emotional exhaustion analyses results for employee's WFC

\begin{tabular}{ccccc}
\hline & Coeff. & s.e. & $t$ & $P$ \\
\hline Direct and total effects & & & & \\
Step 1: PCB to employee's WFC & .45 & .07 & 6.89 & .00 \\
Step 2: PCB to employee's emotional exhaustion & .56 & .06 & 8.90 & .00 \\
Step 3: Employee's emotional exhaustion to employee's & .77 & .05 & 13.99 & .00 \\
$\quad$ WFC, controlling for PCB & & & & \\
Step 4: PCB to employee's WFC, controlling for & .57 & .06 & 1.02 & .31 \\
$\quad \begin{array}{l}\text { employee's emotional exhaustion } \\
\quad\end{array}$ & Mean & s.e. & LL95CI & UL95CI \\
$\begin{array}{l}\text { Sobel test results for the indirect effect of PCB on the } \\
\text { employee's WFC through employee's emotional } \\
\text { exhaustion }\end{array}$ & .40 & .05 & .29 & .50 \\
\hline
\end{tabular}

Note. $\mathrm{PCB}=$ psychological contract breach; WFC = employees' work-family conflict.

Hypothesis 2 states that employees who experience PCB will subsequently experience partners' FWC, mediated by employees' emotional exhaustion. Bootstrap results in the lower half of Table 5 indicate employees' emotional exhaustion mediated the relationship between employees' PCB and partners' FWC. The 95\% confidence interval around the indirect effect did not include zero (from .13 to .32). Step 4 of Table 5 indicates that the relationship between PCB and partners' FWC was not significant when controlling for employees' emotional exhaustion $(t=.79, p>.05)$. Therefore, the results suggest that employees' emotional exhaustion fully mediated the relationship between employees who experienced PCB and partners' FWC, supporting Hypothesis 2.

Table 5. Mediation of employee's emotional exhaustion analyses results for partner's FWC

\begin{tabular}{lcccc}
\hline & Coeff. & s.e. & $t$ & $P$ \\
\hline Direct and total effects & & & & \\
Step 1: PCB to partner's FWC & .29 & .07 & 4.03 & .00 \\
Step 2: PCB to employee's emotional exhaustion & .52 & .06 & 8.90 & .00 \\
$\quad \begin{array}{l}\text { Step 3: Employee's emotional exhaustion to partner's } \\
\text { FWC, controlling for PCB }\end{array}$ & .44 & .08 & 5.83 & .00 \\
$\quad \begin{array}{l}\text { Step 4: PCB to partner's FWC, controlling for } \\
\text { employee's emotional exhaustion }\end{array}$ & .06 & .08 & .79 & .43 \\
& & & & \\
Sobel test results for the indirect effect of PCB on the & .23 & .05 & .13 & .32 \\
partner's FWC through employee's emotional exhaustion & & & & Lalue
\end{tabular}

Note. $\mathrm{PCB}=$ psychological contract breach; $\mathrm{FWC}=$ partners' family-work conflict. 
Table 6. Results of a moderated hierarchical regression analyses for employee's emotional exhaustion and employee's work-family conflict

\begin{tabular}{lllllll}
\hline \multicolumn{5}{l}{ Emotional exhaustion (Med) } \\
\hline Predictors & Step 1 & Step 2 & Step 3 & Step 4 & Step 5 & Step 6 \\
\hline Gender & -1.32 & -1.70 & -.80 & .61 & .75 & 1.44 \\
Age & 1.01 & .42 & .33 & -.54 & 1.61 & 1.46 \\
Children & .60 & 1.27 & 1.18 & 1.22 & 1.37 & .84 \\
Hours & 1.16 & 1.29 & 2.28 & 2.29 & 1.52 & .10 \\
Education & -1.98 & -1.90 & -1.16 & -1.08 & -.37 & .72 \\
Spirituality at work & & $-4.77^{* * *}$ & $-2.33^{*}$ & $-2.52^{* *}$ & $-2.31^{*}$ & .9 \\
PCB & & & $7.30^{* * *}$ & .35 & -.35 & -1.52 \\
EE & & & & & & $5.03^{* * *}$ \\
PCB x Spirituality & & & & $-1.90^{*}$ & $-2.23^{*}$ & $-1.98^{*}$ \\
Spirituality x EE & & & & & & $-1.71 \dagger$ \\
$R^{2}$ & .05 & .14 & .30 & .31 & .22 & .57 \\
Adjusted $R^{2}$ & .03 & .12 & .28 & .29 & .19 & .55 \\
$F$ & $2.49^{*}$ & $22.78^{* * *}$ & $53.24^{* * *}$ & $3.59^{*}$ & $4.97^{*}$ & $2.91^{*}$ \\
\hline
\end{tabular}

Note. $\mathrm{PCB}=$ psychological contract breach; $\mathrm{EE}=$ employees' emotional exhaustion; $\mathrm{WFC}=$ employees' work-family conflict; $\mathrm{Med}=$ mediator; $\mathrm{DV}=$ dependent variable.

$\dagger p<.10 ; * p<.05 ; * * p<.01 ; * * * p<.001$.

Table 7. Results of a moderated hierarchical regression analyses for employee's emotional exhaustion and partner's family-work conflict

\begin{tabular}{|c|c|c|c|c|c|c|}
\hline & Emotional exhaustion (Med) & FWC (DV2) & & & & \\
\hline Predictors & Step 1 & Step 2 & Step 3 & Step 4 & Step 5 & Step 6 \\
\hline Gender & -1.32 & -1.70 & -.80 & .61 & .64 & .84 \\
\hline Age & 1.01 & .42 & .33 & -.54 & $1.70 \dagger$ & 1.52 \\
\hline Children & .60 & 1.27 & 1.18 & 1.22 & .03 & -.35 \\
\hline Hours & 1.16 & 1.29 & 2.28 & 2.29 & -1.04 & -1.82 \\
\hline Education & -1.98 & -1.90 & -1.16 & -1.08 & -1.42 & -1.01 \\
\hline Spirituality at work & & $-4.77 * * *$ & $-2.33 *$ & $-2.52 * *$ & $-5.46 * * *$ & $-3.93 * * *$ \\
\hline PCB & & & $7.30 * * *$ & .35 & $-3.76^{* * * *}$ & $-3.86^{* * *}$ \\
\hline $\mathrm{EE}$ & & & & & & $1.91 *$ \\
\hline PCB x Spirituality & & & & $-1.90 *$ & $-4.62 * * *$ & $-3.92 * * *$ \\
\hline Spirituality x EE & & & & & & -.63 \\
\hline$R^{2}$ & .05 & .14 & .30 & .31 & .20 & .29 \\
\hline Adjusted $R^{2}$ & .03 & .12 & .28 & .29 & .17 & .26 \\
\hline$F$ & $2.49 *$ & $22.78 * * *$ & $53.24 * * *$ & $3.59 *$ & $21.37 * * *$ & $.40^{*}$ \\
\hline
\end{tabular}

Note. $\mathrm{PCB}=$ psychological contract breach; $\mathrm{EE}=$ employees' emotional exhaustion; $\mathrm{FWC}=$ partners' family-work conflict; Med = mediator; DV = dependent variable.

${ }^{*} p<.05 ; * * p<.01 ; * * * p<.001$

In Table 6, the results of the hierarchical multiple regression analyses examined whether spirituality at work 
moderated the relationships between PCB and employees' emotional exhaustion. The result of this study in Table 6 showed that Hypothesis 3 was supported $(t=-1.90, p<.05)$. The link between PCB and employees' emotional exhaustion was still evident even when employee spirituality was high. However, when employee spirituality was high, this relationship was clearly (and, by definition, significantly-see Aiken \& West 1991) weaker. The result shows that high level of PCB was related to increased employees' emotional exhaustion for individuals with low spirituality at work. Thus, employee spirituality was found to moderate the strength of the relationship between PCB and employees' emotional exhaustion.

According to Muller, Judd, and Yzerbyt (2005) study of moderated mediation approaches, Table 6 examines the moderated mediation model presented in Hypotheses $4 \mathrm{a}$ and $4 \mathrm{~b}$. As indicated in Table 6 , the indirect effect of PCB on employees' WFC $(t=5.03, p<.01)$ and partners' FWC in Table $7(t=1.91, p<.05)$ due to employees' emotional exhaustion was weaker for individuals with a high level of employee spirituality. In addition, the results of this study reveal that the indirect effect of PCB on employees' WFC and partners' FWC (mediated by employees' emotional exhaustion) was weaker for employees who possessed high levels of spirituality at work. Moreover, employees' emotional exhaustion also mediated the moderating effect of employee spirituality at work on the relationships between PCB and employees' WFC and partners' FWC. This finding supported hypotheses $4 \mathrm{a}$ and $4 \mathrm{~b}$.

\section{Discussion}

The result of this study was to discover whether the consequences of PCB extended beyond the employees' work domain to affect the family domain for both employees and their spouses. Many prior studies have aimed at the relationship between work and family domains (e.g., Culbertson, Mills, \& Fullagar, 2012; Lee, Kossek, Hall, \& Litrico, 2010), however, only a limited total of research has investigated the effects of PCB on partners' issues, particularly with respect to spillover and crossover effects. This study provides the importance by investigating the relationships that exist between PCB, employees' WFC, and partners' FWC, as mediated by employees' emotional exhaustion. In addition, the results revealed that the employees with PCB experienced WFC due to emotional exhaustion.

The findings of this study also fill a gap that shows clear links between PCB, emotional exhaustion, and subsequent negative family outcomes (that is, employee WFC and partner FWC). According to stress transmission (Ferguson, 2012), emotional exhaustion spilled over into the family domain to influence employees' WFC and partners' FWC. These results suggest that employees do not leave their emotional exhaustion in company; rather, they bring negative emotions home with them, where the emotions may affect employees' family responsibilities.

With respect to the role of spirituality as a buffering role, this study discovered that employees with high spirituality were better able to cope with emotional exhaustion in their jobs, thus experiencing lower levels of employees' emotional exhaustion, employees' WFC, and partners' FWC than employees who had relatively lower spirituality. These results of this study suggest that employees have to manage emotional exhaustion in the workplace. It might be tempting to suggest that employees with spirituality at work have both an inner and outer life. Fox (1994) also mentioned that the nourishment of inner life can result in a more meaningful outer life. Therefore, this study suggests that organizations or employers should provide employees with mental and emotional training. The author hopes that the results of this study can help employers better understand what they can offer useful supports to their employees and partners.

\subsection{Limitations and Future Research}

Some limitations of this study should be acknowledged. First, this study followed the dominant research stream in this field by focusing on what employees perceive employers owe them (i.e., PCB), not on what employees feel they owe employers (i.e., psychological contract violation, PCV). However, this discrepancy needs to be adopted in further research if researchers sincerely believe that the psychological contracts represent mutual understandings of contributions and inducements (Dulac et al., 2008; Lambert et al., 2003; Zhao et al., 2007).

Second, the goal of this study is to understand how PCB can transmit to family domains and what a buffer can be against emotional exhaustion and WFC. Therefore, this study could exist in the validity issues of spirituality at work. Even though prior research used the spirituality at work scale as a convergent validity (Chang, Liou, \& Huang, 2011), this study suggests that future research needs to work concerning discriminant and convergent validity issues of construct of spirituality at work.

\subsection{Implications}

Despite the above limitations, this study makes some main contributions to both PCB and work to family 
literature. The first theoretical contribution aims at its examination of emotional exhaustion as a mechanism by which the effects of PCB develop to impact employees' partners in family domain. The current research observed spillover effects associating with employees' WFC, and crossover effects of PCB on partners' FWC. Although previous research has implied a relationship between the spillover effects of job strain, such as stress transmission, and FWC, we focused on PCB as the specific substance of these effects.

The results of this study also have key practical contributions for organizations and their employers. Previous studies have mentioned that PCB has general organizational contributions, such as lower level of job satisfaction (Lambert, 2011) and increases the level of turnover intentions (Proost et al., 2012). In contradiction of the effects of PCB on the work domain, research on the effects of PCB on the family domain is relatively growing. Therefore, the results of this study strongly suggest that breached employees with emotional exhaustion do not remain in the organization; rather, it is carried home, where it exerts influences on partners' FWC. To reduce employees' WFC and partners' FWC, in addition, employers may also consider a work-family balance by organizational policy to avoid employees' family issues and to increase a work-family support (Allen, 2001). Therefore, employees may focus on work demands in the workplace and leave their negative emotions before returning home.

While the findings of this study may suggest that employers should try to minimize the effects of PC breaches by playing an active role in discouraging unmet expectations and improving reliance and expectations with respect to employment contracts, this study tests the moderating effect of the employee spirituality. In addition, this study finds that employees with higher levels of employee spirituality are less sensitive to the negative effects of PCB (i.e., emotional exhaustion and corresponding WFC and FWC) because they may have positivity and inner strength.

\section{Conclusion}

This study demonstrates that PCB leads to emotional exhaustion, and transmits to partners in the family domain. The author hopes that the current research stimulates further examination of the relationships between PCB and family issues and different types of conflict between work and family domains. In addition, this study encourages future studies to focus on how employees deal with the various issues of work and family and give more careful attention to how spiritual involvement enhances the relationship between work life and family life. Finally, this study suggests future studies will consider a generalizability problem for such sample. The generalizability is potential that different contexts may generate different consequences.

\section{References}

Aiken, S., \& West, S. G. (1991). Multiple regression: Testing and interpreting interactions. New York, NY: Sage.

Allen, T. D. (2001). Family-supportive work environments: The role of organizational perceptions. Journal of Vocational Behavior, 58, 414-435. http://dx.doi.org/10.1006/jvbe.2000.1774

Andrews, F. M., \& Withey, S. B. (1976). Social indicators of well-being: Americans perceptions of life quality. New York: Plenum Press.

Aselage, J., \& Eisenberger, R. (2003). Perceived organizational support and psychological contracts: A theoretical integration. Journal of Organizational Behavior, 24, 491-509. http://dx.doi.org/10.1002/job.211

Ashmos, D. P., \& Duchon, D. (2000). Spirituality at work: A conceptualization and measure. Journal of Management Inquiry, 9, 134-145. http://dx.doi.org/10.1108/09534810010378597

Bakker, A. B., \& Demerouti, E. (2007). The job demands-resources model: State of the art. Journal of Managerial Psychology, 22, 309-328. http://dx.doi.org/10.1108/02683940710733115

Bakker, A. B., Demerouti, E., \& Dollard, M. F. (2008). How job demands affect partners' experience of exhaustion: Integrating work-family conflict and crossover theory. Journal of Applied Psychology, 93, 901-911. http://dx.doi.org/10.1037/0021-9010.93.4.901

Bal, P. M., De Lange, A. H., Jansen, P., \& Van Der Velde, M. G. (2008). Psychological contract breach and job attitudes: A meta-analysis of age as a moderator. Journal of Vocational Behavior, 72, 143-158. http://dx.doi.org/10.1016/j.jvb.2007.10.005

Bal, P. M., \& Kooij, D. (2011). The relations between work centrality, psychological contracts, and job attitudes: The influence of age. European Journal of Work and Organizational Psychology, 20, 497-523. http://dx.doi.org/10.1080/13594321003669079

Baron, R. M., \& Kenny, D. A. (1986). The moderator-mediator variable distinction in social psychological 
research: Conceptual, strategic, and statistical considerations. Journal of Personality \& Social Psychology, 51, 1173-1182. http://dx.doi.org/10.1037/0022-3514.51.6.1173

Carlson, D. S., Kacmar, K. M., \& Williams, L. J. (2000). Construction and initial validation of a multidimensional measure of work-family conflict. Journal of Vocational Behavior, 56, 249-276. http://dx.doi.org/10.1006/jvbe.1999.1713

Cassar, V., \& Briner, R. B. (2011). The relationship between psychological contract breach and organizational commitment: Exchange imbalance as a moderator of the mediating role of violation. Journal of Vocational Behavior, 78, 283-289. http://dx.doi.org/10.1016/j.jvb.2010.09.007

Chambel, M. J., \& Oliveira-Cruz, F. (2010). Breach of psychological contract and the development of burnout and engagement: A longitudinal study among soldiers on a peacekeeping mission. Military Psychology, 22, 110-127. http://dx.doi.org/10.1080/08995601003638934

Chang, H. T., Liou, J. W, \& Huang, M. Y. (2010). The effects of workplace spirituality on work family balance: The integrating Model. Taiwan Academy of Management Journal, 10, 79-102.

Conway, N., Guest, D., \& Trenberth, L. (2011). Testing the differential effects of changes in psychological contract breach and fulfillment. Journal of Vocational Behavior, 79, 267-276. http://dx.doi.org/10.1016/j.jvb.2011.01.003

Culbertson, S. S., Mills, M. J., \& Fullagar, C. J. (2012). Work engagement and work-family facilitation: Making homes happier through positive affective spillover. Human Relations, 65(9), 1155-1177. http://dx.doi.org/10.1177/0018726712440295

Dulac, T., Coyle-Shapiro, J. M., Henderson, D., \& Wayne, S. (2008). Not all responses to breach are the same: A longitudinal study examining the interconnection of social exchange and psychological contract processes in organizations. Academy of Management Journal, 51(6), 1079-1098. http://dx.doi.org/10.5465/AMJ.2008.35732596

Edwards, J. E., \& Rothbard, N. P. (2000). Mechanism linking work and family: Clarifying the relationship between work and family constructs. Academy of Management Review, 25(1), 178-199. http://dx.doi.org/10.5465/AMR.2000.2791609

Edwards, J. R., \& Lambert, L. S. (2007). Methods for integrating moderation and mediation: A general analytical framework using moderated path analysis. Psychological Methods, 12, 1-22. http://dx.doi.org/10.1037/1082-989X.12.1.1

Ferguson, M. (2012). You cannot leave it at the office: Spillover and crossover of coworker incivility. Journal of Organizational Behavior, 33, 571-588. http://dx.doi.org/10.1002/job.774

Frone, M. R., Russell, M., Cooper, M. L. (1992). Antecedents and outcomes of work-family conflict: Testing a model of the work-family interface. Journal of Applied Psychology, 77, 65-78. http://dx.doi.org/10.1037/0021-9010.77.1.65

Fox, M. (1994). The Reinvention of Work: A New Vision of Livelihood for Our Time. San Francisco, CA: Harper San Francisco.

Greenhaus, J. H., \& Beutell, N. J. (1985). Sources of conflict between work and family roles. Academy of Management Review, 10, 76-88. http://dx.doi.org/10.5465/AMR.1985.4277352

Gooke, R., \& Rousseau, D. (1984). Stress and strain from family roles and work-role expectations. Journal of Applied Psychology, 69, 252-260. http://dx.doi.org/10.1037/0021-9010.69.2.252

Gutek, B. A., Searle, S., \& Klepa, L. (1991). Rational versus gender role explanations for work-family conflict. Journal of Applied Psychology, 76, 560-568. http://dx.doi.org/10.1037/0021-9010.76.4.560

Hackman, J. R., \& Oldham, G. R. (1975). Development of the job diagnostic survey. Journal of Applied Psychology, 60, 159-170. http://dx.doi.org/10.1037/h0076546

Hobfoll, S. E. (1989). Conservation of Resources: A new attempt at conceptualizing stress. American Psychologist, 44, 513-524. http://dx.doi.org/10.1037/0003-066X.44.3.513

Hoobler, J. M., \& Brass, D. J. (2006). Abusive Supervision and Family Undermining as Displaced Aggression. Journal of Applied Psychology, 91, 1125-1133. http://dx.doi.org/10.1037/0021-9010.91.5.1125

Hoobler, J. M., \& Hu, J. (2013). A model of injustice, abusive supervision, and negative affect. The Leadership Quarterly, 24, 256-269. http://dx.doi.org/10.1016/j.leaqua.2012.11.005 
Hu, L., \& Bentler, P. M. (1998). Fit indices in covariance structure modeling: Sensitivity to underparameterized model misspecification. Psychological Methods, 3, 424-453. http://dx.doi.org/10.1037/1082-989X.3.4.424

Hu, L., \& Bentler, P. M. (1999). Cutoff criteria for fit indexes in covariance structure analysis: Conventional criteria versus new alternatives. Structural Equation Modeling, 6, 1-55. http://dx.doi.org/10.1080/10705519909540118

Kutcher, E. J., Bragger, J. D., Rodriguez-Srednicki, O., \& Masco, J. L. (2010). The Role of Religiosity in Stress, Job Attitudes, and Organizational Citizenship Behavior. Journal of Business Ethics, 95, 319-337. http://dx.doi.org/10.1007/s10551-009-0362-z

Laabs, J. J. (1995). Balancing Spirituality and Work. Personnel Journal, 74, 60-69.

Lambert, L. S., Edwards, J. R., \& Cable, D. M. (2003). Breach and fulfillment of the psychological contract: A comparison of traditional and expanded views. Personnel Psychology, 56, 895-934. http://dx.doi.org/10.1111/j.1744-6570.2003.tb00244.x

Lambert, L. S. (2011). Promised and Delivered Inducements and Contributions: An Integrated View of Psychological Contract Appraisal. Journal of Applied Psychology, 96, 695-712. http://dx.doi.org/10.1037/a0021692

Lee, R. T., \& Ashforth, B. E. (1996). A meta-analytic examination of the correlates of the three dimensions of job burnout. Journal of Applied Psychology, 81, 123-133. http://dx.doi.org/10.1037/0021-9010.81.2.123

Lee, M. D., Kossek, E. E., Hall, D. T., \& Litrico, J. B. (2010). Entangled strands: A process perspective on the evolution of careers in the context of personal, family, work, and community life. Human Relations, 64, 1531-1553. http://dx.doi.org/10.1177/0018726711424622

Maslach, C., \& Jackson, S. E. (1981). The measurement of experienced burnout. Journal of Occupational Behaviour, 2, 99-113. http://dx.doi.org/10.1002/job.4030020205

Maslach, C., Schaufeli, W., B., \& Leiter, M. P. (2001). Job burnout. Annual Review of Psychology, 52, 397-422. http://dx.doi.org/10.1146/annurev.psych.52.1.397

Montes, S. D., \& Irving, P. G. (2008). Disentangling the effects of promised and delivered inducementsRelational and transactional contract elements and the mediating role of trust. Journal of Applied Psychology, 93, 1367-1381. http://dx.doi.org/10.1037/a0012851

Morrison, E. W., \& Robinson, S. L. (1997). When employees feel betrayed: A model of how psychological contract violation develops. The Academy of Management Review, 22, 226-256. http://dx.doi.org/10.5465/AMR.1997.9707180265

Muller, D., Judd, C. M., \& Yzerbyt, V. Y. (2005). When Moderation Is Mediated and Mediation Is Moderated. $\begin{array}{llllll}\text { Journal of Personality and Social Psychology, } & 89, & \text { 852-869. }\end{array}$ HTTP://DX.DOI.ORG/10.1037/0022-3514.89.6.852

Nohe, C., Michel, A., \& Sonntag, K. (2014). Family-work conflict and job performance: A diary study of boundary conditions and mechanisms. Journal of Organizational Behavior, 35, 339-357. http://dx.doi.org/10.1002/job.1878

Preacher, K. J., \& Hayes, A. F. (2004). SPSS and SAS procedures for estimating indirect effects in simple mediation models. Behavior Research Methods, Instruments, \& Computers, 36, 717-731. http://dx.doi.org/10.3758/BF03206553

Preacher, K. J., \& Hayes, A. F. (2008). Asymptotic and resampling strategies for assessing and comparing indirect effects in multiple mediator models. Behavior Research Methods, 40, 879-891. http://dx.doi.org/10.3758/BRM.40.3.879

Proost, K., Ruysseveldt, J., \& Dijke, M. (2012). Coping with unmet expectations: Learning opportunities as a buffer against emotional exhaustion and turnover intentions. European Journal of Work and Organizational Psychology, 21, 7-27. http://dx.doi.org/10.1080/1359432X.2010.526304

Rego, A., \& Cunha, M. P. (2008). Workplace spirituality and organizational commitment: an empirical study. Journal of Organizational Change Management, 21, 53-75. http://dx.doi.org/10.1108/09534810810847039

Repetti, R. I. (1994). Short-term and long-term processes linking job stressors to father-child interaction. Social Development, 3, 1-15. http://dx.doi.org/10.1111/j.1467-9507.1994.tb00020.x 
Restubog, S. L. D., Bordia, P., \& Bordia, S. (2011). Investigating the role of psychological contract breach on career success: Convergent evidence from two longitudinal studies. Journal of Vocational Behavior, 79, 428-437. http://dx.doi.org/10.1016/j.jvb.2011.01.006

Robinson, S. L., \& Morrison, E. W. (2000). The development of psychological breach and violation: A longitudinal study. Journal of Organizational Behavior, 21, 525-546.

Rousseau, D. M. (1989). Psychological and implicit contracts in organizations. Employee Responsibilities and Rights Journal, 2, 121-139.

Schaufeli, W. B., Leiter, M. P., Maslach, C., \& Jackson, S. E. (1996). The MBI-General Survey. In C. Maslach, S. E. Jackson, \& M. P. Leiter (Eds.), Maslach Burnout Inventory (pp. 19-26). Palo Alto, CA: Consulting Psychologists Press.

Schwab, R. L., Jackson, S. E., \& Schuler, R. S. (1986). Educator burnout: Sources and consequences. Educational Research Quarterly, 10, 14-30.

Staines, G. L. (1980). Spillover versus compensation: A review of the literature on the relationship between work and nonwork. Human Relations, 33, 111-1129. http://dx.doi.org/10.1177/001872678003300203

Vaill, P. (1998). Spirited leading and learning. San Francisco: Jossey-Bass.

Weiss, H. M., \& Cropanzano, R. (1996). Affective events theory: A theoretical discussion of the structure, causes and consequences of affective experiences at work. In B. M. Staw, \& L. L. Cummings (Eds.), Research in organizational behavior: An annual series of analytical essays and critical reviews (pp. 1-74). Greenwich, CT: Jai Press.

Westman, M. (2001). Stress and strain crossover. Human Relations, 54, 717-751. http://dx.doi.org/10.1177/0018726701546002

Westman, M., \& Etzion, D. (1995). Crossover of stress, strain and resources from one spouse to another. Journal of Organizational Behavior, 16, 169-181. http://dx.doi.org/10.1002/job.4030160207

Westman, M., \& Etzion, D. (2005). The crossover of work-family conflict from one spouse to the other. Journal of Applied Social Psychology, 35, 1936-1957. http://dx.doi.org/10.1111/j.1559-1816.2005.tb02203.x

Westman, M., Vinokur, A. D., Hamilton, L. V., \& Roziner, I. (2004). Crossover of marital dissatisfaction during downsizing among Russian army officers and their spouses. Journal of Applied Psychology, 89, 769-779. http://dx.doi.org/10.1037/0021-9010.89.5.769

Wheatley, M. J. (1992). Leadership and the new science. San Francisco: Berrett-Koehler.

Zhao, H., Wayne, S. J., Glibkowski, B. C., \& Bravo, J. (2007). The impact of psychological contract breach on work-related outcomes: A meta-analysis. Personnel Psychology, 60, 647-680. http://dx.doi.org/10.1111/j.1744-6570.2007.00087.x

\section{Copyrights}

Copyright for this article is retained by the author(s), with first publication rights granted to the journal.

This is an open-access article distributed under the terms and conditions of the Creative Commons Attribution license (http://creativecommons.org/licenses/by/3.0/). 